\title{
Special Issue Introduction: Ecological Modernization
}

\author{
ILMO MASSA ${ }^{\mathbf{a}}$ AND MIKAEL SKOU ANDERSEN ${ }^{\mathbf{b}, *}$ \\ a Department of Social Policy, University of Helsinki, Finland \\ b Department of Political Science, Aarhus University, Århus, Denmark
}

Nowadays, there are more and more critics who ask what 'ecological modernization' offers that distinguishes it from the 'business as usual' of contemporary capitalism. Is ecological modernization merely a cornucopian concept, which promises with hollow ringing optimism that more efficiency and new technology will save us from the environmental crisis? Like the concept of sustainable development, ecological modernization has risen to political prominence. But has efficiency in resource and energy use, as well as technological innovation, not always been a standard operating mechanism of a freemarket economy?

Former European Commission President, Jacques Delors, and his think-tank Cellule de Prospective were soon to integrate ecological modernization ideas into the 1993 White Paper on growth, competitiveness and employment (CEC, 1993). Furthermore, international financial institutions, including the World Bank, have eloquently expanded their vocabulary to include new green buzzwords. With little doubt, the present crisis for concepts such as sustainable development and ecological modernization is a result of their heuristic and sometimes flagrant uses, which have caused a steady erosion of the specificity that was once linked to them. The pragmatic use of these concepts - not only among actors with mixed political motives, but also by many environmental agencies and institutions - have blunted our senses for their potential analytical sharpness and significance, and they threaten to turn them into empty phrases, a contemporary form of 'greenspeak'.

* Correspondence to: Department of Political Science, Aarhus University, Universitetsparken bygn. 331, DK-8000 Århus C, Denmark. Tel: + 458942 1133; fax: + 458613 9839; e-mail: andersen@ps.au.dk

Copyright (C) 2000 John Wiley \& Sons, Ltd.
It is against this background that we should judge the possible value of the academic debate that has developed in recent years and that recently has evidenced an upsurge of interest in ecological modernization ideas (Hajer, 1995; Mol, 1995; Mol \& Sonnenfeld, 2000; Murphy, 2000). Although Buttel (2000) may be right in pointing out that it is daring to speak of an ecological modernization theory per se, it is hard to deny that there has been a marked discursive orientation towards researching the implications of ecological modernization, internationally as well as within the sectors of advanced industrial economies. As Anthony Giddens states in his The Third Way, 'there is no doubt that ecological modernisation links social, democratic and ecological concerns more closely than once seemed possible' (Giddens, 1998, pp. 57-58).

The contributions to this special issue of the Journal of Environmental Policy and Planning stem from an international conference on ecological modernization that took place at the Department of Social Policy of the University of Helsinki, Finland, in late 1998. They have been selected, among other reasons, for their possible contribution to conceptual understanding and clarification. While recent publications have explored the implications of ecological modernization in different settings (Mol \& Sonnenfeld, 2000), here we try to put the concept under the microscope again, in the hope of clarifying and restoring its meaning and justification for the environmental debate.

In the first contribution, Joseph Huber, one of the originators of the ecological modernization idea, explores the different perceptions of sustainable development that have developed in the course of the Brundtland report. He argues that the ecology movement sticks to a tradi- 
tionalist sufficency interpretation, which emphasizes the confinement of consumption and production, while industry, on the other hand, has not realized its potential role in the ecological transformation, but clings to a conventional efficiency interpretation of sustainability, which does not seriously pay attention to new types of technologies or modes of production. He also argues for a consistency version of sustainable development, i.e. a programme for innovation of new technologies, products and material flows in order to change the qualities of industrial metabolism, as the only path that allows for a true industrial ecology.

Ørnulf Seippel, in the next contribution, focuses on the concept of ecological modernization and explores the meanings attributed to it in recent literature. From a discussion of different interpretations, he reaches the conclusion that the notion of ecological modernization basically represents a normative change in the discourse of environmental policy. However, he also notes that the literature is marked by a tendency to slide from the specific perspective to a description of the changes linked with ecological modernization in a more general way. As such, ecological modernization is not (yet) a body of theory, but rather a case-based inductive description of a development trend prevalent in several industrialized countries. Seippel goes further, however, and evaluates ecological modernization as a theoretical concept. There is still a need for clearer answers as to exactly which discourses of ecological modernization are relevant and what these discourses have as references. There are also diverging views as to how these discursive formations fit into the larger historical context of complex modernity. A fruitful analysis of ecological modernization should, somehow, reflect this complexity and not reduce it merely to instrumental politics.

Oluf Langhelle undertakes a careful, semantic analysis of the key differences between the concepts of sustainable development and ecological modernization. As Langhelle's contribution clearly shows, there are significant differences between these two ways of framing an approach to environmental policy. The concept of sustainable development is closely tied to global environmental problems and the issue

Copyright (C) 2000 John Wiley \& Sons, Ltd. of global justice. The concept of ecological modernization, on the other hand, mainly addresses the environmental problems of the industrialized countries and does not raise global distributional questions. Therefore, ecological modernization should be seen as a necessary component of sustainable development, but not a sufficient alternative. In what amounts to a 'defence' of the concept of sustainable development, Langhelle warns us not to conflate it with ecological modernization.

Gert Spaargaren contends that ecological modernization needs to be understood in broader terms than the narrow engineering approach that prevails in many instances, but which he regards as misleading. He argues that sociologists can contribute to and establish a broad research field on ecological modernization, by focusing on two basic aspects that are not fully recognized by other disciplines. First, the importance of the role of human agency in bringing about more sustainable production and consumption arrangements. Second, the re-evaluation of production-consumption arrangements from a consumer-oriented perspective. The challenge is to put the celebrated western way of life in a physical, energetic and ecological context. This discussion has been marginally a part of 'consumer sociology', but not at all a part of 'life-style sociology'.

Mikael Skou Andersen \& Ilmo Massa return to the origins of the ecological modernization debate in the 1980s and show how intimately the concept is linked to the long-term perspective of the precautionary principle. Despite insistence on the opportunities for a harmonization of ecology and economy, it is also a concept that is fundamentally at odds with traditional neoclassical economics and its focus on short-term efficiency. However, from empirical, technology-oriented studies it appears that ecological modernization without technological and structural change does not seem to bring about environmental change. Andersen \& Massa argue further that if ecological modernization is about structural change, the conceptual linkage to the precautionary principle needs to be explored by addressing the role of the state in a more direct and critical way.

J. Environ. Policy Plann. 2: 265-267 (2000) 


\section{References}

Buttel F. 2000. Ecological modernisation as social theory. Geoforum 31: 57-65.

Commission of the European Communities (CEC) 1993. Growth, Competitiveness, Employment: The Challenges and Ways Forward into the 21st Century. White Paper, $\mathrm{COM} / 93 / 700,5.12 .1993$. Office for Official Publications of the European Communities: Luxembourg.

Giddens A. 1998. The Third Way: The Renewal of Social Democracy. Polity Press: Cambridge.
Hajer M. 1995. The Politics of Environmental Discourse: Ecological Modernization and the Policy Process. Oxford University Press: Oxford.

Mol A. 1995. The Refinement of Production: Ecological Modernization Theory and the Chemical Industry. Van Arkel: Utrecht.

Mol A, Sonnenfeld D. 2000. Ecological modernisation around the world: an introduction. Environmental Politics 9: 3-16.

Murphy J. 2000. Ecological modernisation. Geoforum 31: $1-8$. 